OPEN ACCESS

Citation: E.-J. Díez-Gutiérrez, K. Gajardo Espinoza (2020) Valuations by Spanish university students on online assessment in times of pandemic. Media Education 11(2): 85-92. doi: 10.36253/me-9619

Received: August, 2020

Accepted: September, 2020

Published: December, 2020

Copyright: @ 2020 E.-J. Díez-Gutiérrez, K. Gajardo Espinoza. This is an open access, peer-reviewed article published by Firenze University Press (http:// www.fupress.com/me) and distributed under the terms of the Creative Commons Attribution License, which permits unrestricted use, distribution, and reproduction in any medium, provided the original author and source are credited.

Data Availability Statement: All relevant data are within the paper and its Supporting Information files.

Competing Interests: The Author(s) declare(s) no conflict of interest.

\section{Valuations by Spanish university students on online assessment in times of pandemic}

\section{Lopinione degli studenti universitari spagnoli rispetto alla valutazione online nel periodo della pandemia}

\author{
Enrique-Javier DíEZ-GutiérreZ ${ }^{1}$, Katherine Gajardo Espinoza² \\ 1 University of León, Spain, Campus de Vegazana, s/n, 24071 León, Spain \\ 2 University of Valladolid, Spain, Plaza de la Universidad, 1, 40005 Segovia, Spain. \\ E-mail: enrique.diez@unileon.es; Katherine.gajardo@usach.cl
}

\begin{abstract}
This study describes the assessment that university students make regarding the model of evaluation of Higher Education during the period of confinement by COVID-19 in Spain. We developed a descriptive study through an online questionnaire designed from the assessment and qualification proposals presented by Spanish Network of University Quality Agencies (REACU), The National Agency for Quality Assessment and Accreditation (ANECA), UNESCO and the Spanish Ministry of Universities. Following its application to a sample of 1008 students from across the country, it is observed that university students demand greater flexibility in online assessment, introduce learning-oriented assessment practices in accordance with a formative and continuous assessment approach, in addition to using various strategies and instruments. However, they are reluctant to introduce peer evaluation mechanisms, although they do propose democratic evaluation. The future of Higher Education, after COVID-19, is adopting hybrid and mixed models of training and evaluation, so it is imperative to investigate students' vision and analyse the practices developed during the crisis to reinforce an assessment in Higher Education that ensures equity and enhances learning.
\end{abstract}

Keywords: university, e-evaluation, online learning, meaningful learning, e-learning, COVID-19.

Riassunto. Lo studio documenta l'opinione degli studenti universitari spagnoli rispetto al tema della valutazione durante il periodo di lockdown dovuto al COVID-19. Lo studio descrittivo è stato condotto attraverso un questionario online progettato dalla Rete spagnola delle agenzie di qualità universitaria (REACU), l'Agenzia nazionale per la valutazione e l'accreditamento della qualità (ANECA), l'UNESCO e il Ministero spagnolo dell'Università. In seguito alla sua compilazione da parte di un campione di 1008 studenti di tutto il paese, emerge che gli studenti universitari richiedono una maggiore flessibilità nella valutazione online, introducendo pratiche di valutazione orientate all'apprendimento in conformità con un approccio formativo e continuo alla valutazione. Tuttavia, gli studenti sono riluttanti a introdurre meccanismi di valutazione tra pari, sebbene propongano una valutazione democratica. Il futuro dell'istruzione supe- 
riore, dopo il COVID-19, guarda all'adozione di modelli ibridi e misti di formazione e valutazione, quindi è imperativo indagare sulla visione degli studenti e analizzare le pratiche sviluppate durante la crisi per rafforzare una valutazione che assicuri equità e miglioramento dell'apprendimento nel mondo dell'università.

Parole chiave: università, valutazione online, apprendimento online, apprendimento significativo, e-learning, COVID-19.

\section{INTRODUCTION}

The COVID 19 pandemic forced nations to close the doors of more than 20,000 Higher Education institutions and about 200 million students had to follow their training and be evaluated online (UNESCO, 2020a).

In Spain, the government decreed population confinement in March and it was recommended that educational activities be moved to remote and online modalities, whenever possible (Government of Spain, 2020). Universities, in this context, had to improvise a system to adapt not only the teaching and learning process to the online format, but also the evaluation of this (Zubillaga \& Gortazar, 2020).

The conference of rectors of the Spanish universities (Silió, 2020) and the Spanish Network of University Quality Agencies (REACU) established that the evaluation methodologies had to be adapted to the quality standards in force in the European Higher Education Area (Rodríguez-Conde \& Herrera, 2010), following criteria such as: (1) the use of different evaluation methods, based on continuous evaluation techniques and individual tests; (2) assess the acquisition of skills and not just learning outcomes; and (3) that the evaluation and qualification criteria and methods were made public well in advance (REACU, 2020). In order for all students to have an appropriate and, above all, fair assessment (ANECA, 2020). UNESCO (2020a) also raised the need to combine different assessment tests, adapt to the psychosocial situation of students, as well as take measures to ensure inclusion and select technologies that would ensure data protection.

These institutional recommendations, together with those of the Ministry of Universities (2020), were implemented by the Spanish Universities, proposing alternative methods to the single examination and opting for continuous evaluation with individual or group work, exercises and tests whose responses required a reflection work or even through videoconferences, proposing that the final note be distributed among the various activities and that could be carried out at different times, decreasing the weight of the final exam, although the multiplechoice tests (Abella et al., 2020) were also maintained.

It is necessary to understand that the context of Higher Education in Spain has been mostly face-to-face: in $2019,81.1 \%$ of the total number of students enrolled attended face-to-face classes and online education is mainly covered by the 33 private universities (Torrecillas, 2020). However, $7 \%$ of public universities maintain non-face-to-face or blended learning programmes in the 2018-2019 (EDUCAbase, 2020) academic year.

The emergence of the COVID 19 crisis forced the application of methods linked to distance learning and evaluation in an emergency context - or a model of emergency e-learning - (Habib et al., 2020). The answer given, being improvised in a very short time, had difficulty generating a comprehensive approach to the evaluation of subjects that were originally intended to be taught in person or blended (García-Peñalvo et al., 2020). For that reason, difficulties were tackled as they arose. (Llorens-Largo \& Fernández, 2020), since all the actors of the educative process did not count on technological means required, the necessary digital abilities or a positive attitude before the change. So, the process has proved difficult for teachers (Torrecillas, 2020; Villén Sánchez, 2020), families (Díez-Gutiérrez \& Gajardo, 2020; Muñoz-Moreno \& Lluch, 2020) and students (Ozamiz-Etxebarria et al., 2020; Lozano-Díaz et al., 2020).

Another underlying problem is that, in Higher Education, there has been a tendency to overemphasize exams (Azambuya, 2020), ignoring more comprehensive assessment (Barrientos \& López-Pastor, 2017), with a focus towards strategic, autonomous and self-regulation of the learning process itself (Zimmerman, 2002). An approach consistent with the online evaluation indications that the various national and international agencies have proposed in a crisis context.

In this context, we believe that this crisis may be an opportunity to move from an exam culture to a culture of learning-oriented evaluation, applying online assessment methods that allow to evaluate what students can do with knowledge in a contextualized, shared and constructivist way (Oliveri \& Markle, 2017), that consolidates the use of superior cognitive skills (Bloxham et al., 2016), to solve relevant problems related to the life and professional field in which they will be developed (Saye, 2013).

Hence the objective of this research has been to investigate from the perspective of the students, how the evaluation process in Higher Education has developed 
during the confinement by COVID-19 in Spain. Identifying their assessments of the evaluation systems and strategies that have been proposed in Higher Education during the months of March to May 2020. This study thus seeks to provide relevant information, which can be useful for short-, medium- and long-term decision-making on higher education assessment in the post-pandemic education future.

Materials and methods

The study was carried out with a quantitative methodology, based on the design, application and analysis of an online questionnaire, generated ad hoc, which was answered voluntarily by 1008 university students from the 17 Autonomous Communities of Spain (convenience sample).

An initial questionnaire was designed considering instruments already validated with similar themes (Trillo, 2005; López \& Palacios, 2012).

The objectives of the survey arose from the lack of exploratory and descriptive studies and the approach of two research questions: How do students rate the guidelines on university evaluation provided by the universities against covid-19? What are the main issues that arise when they are asked to express their needs, concerns, and experiences with academic evaluation during confinement?

The questionnaire validation process took 3 moments: (1) The drafting of items and questions based on institutional proposals established by REACU, the Spanish Network of University Quality Agencies (2020b), ANECA, the National Agency for Quality Assessment and Accreditation (2020), UNESCO (2020a, 2020b) and the Ministry of Universities (2020), as well as coordinated proposals between different universities (Abella et al., 2020). The proposals were mainly expressed in 4 recommendations: promoting formative assessment instruments; generating ongoing evaluations; protecting students' personal information; and generating more fair evaluations in the context of the pandemic.

(2) The review of items and questions using a Delphi technique, in which 12 experts assessed the quality and relevance of the questionnaire. (3) A pilot with a sample of 23 students. At this point, academics from 6 Spanish universities analysed the questions initially developed by the research team by observing them and comparing them with the institutional proposals established under the criteria of quality and relevance.

The final version of the questionnaire was imported into Google forms. It was disseminated massively and simultaneously through professional contacts, research networks in Higher Education and official social network accounts of university institutions.
With the overall sample, 1008 cases after database debugging - mostly women (74\%), young people aged 18 to $24(87 \%)$ and mainly from the medium-low socioeconomic sector (55\%) - an internal consistency calculation was performed with Cronbach's Alpha, with the p-values of $0.76 ; 0.85$ and 0.93 acceptable according to George and Mallery's theory (2003) obtained for the scales of each section.

The final version of the questionnaire consisted of 22 questions designed to probe the following: (1) the sociodemographic characterization of the sample and (2) its perceptions and assessments with respect to the following topics:

- Measures taken by universities regarding online evaluation during confinement.

- Instruments for a fair online evaluation.

- Continuous evaluation.

- Control and surveillance mechanisms in online evaluation.

- Fair online rating.

- Online peer evaluation.

- Rubrics and online evaluation scales.

Two open-ended questions were added at the end of the questionnaire in which students could express their needs, concerns and experiences with the evaluation during confinement.

The obtained data was imported from the database offered by Google forms to the IBM ${ }^{\oplus}$ SPSS Statistics 26 Software. Subsequently, the cases were codified, recoded and grouped together to proceed with descriptive and frequency statistical analyses. Open questions were analysed through qualitative content analysis (Abela, 2002). Below are some of the most noteworthy research results.

\section{RESULTS}

Much of the students surveyed (72\%) demand that, in the emergency situation caused by COVID-19, an online evaluation be maintained and that neither teaching activity (73.3\%) nor evaluation (75.3\%) be suspended.

90.3\% think it should be evaluated through jobs, projects and portfolios to make the assessment "fairer", although $52.3 \%$ of participants also consider maintaining multiple-choice exams or short questions.

About the use of surveillance programs during online examinations (with facial recognition or remote virtual surveillance technologies) different postures are observed: 


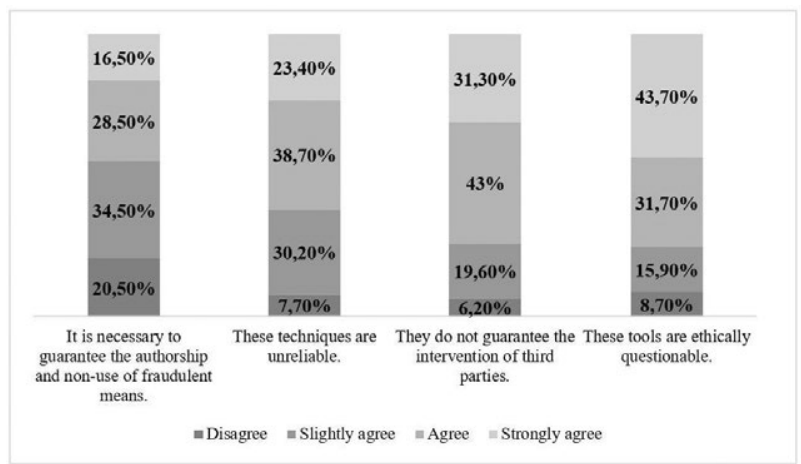

Figure 1. Use of Software that certifies authorship and surveillance (\%).

Students agree or strongly agree (94\%) with the proposal that evaluation should be continuous - done throughout the course and not only at the end of it - offering different possibilities and ways to evaluate the knowledge acquired, from examinations to essays, through case resolution, projects, exhibitions, oral defence of assignments, etc. Also the vast majority (94.4\%) consider that Universities should ensure some form of a subsequent face-to-face evaluations for those students who have justifiably not been able to access the telematics evaluation, either due to lack of access to resources or other circumstances, and that those activities that need to be in person (laboratory, sports tests) should be deferred.

When look into grades, opinions become more diverse and even dissenting. When asked if, in this emergency, a general promotion should be applied - as has been raised publicly in some countries (UNESCO, $2020 \mathrm{~b}$ ) and by some sectors (Luengo \& Manso, 2020) - $75.7 \%$ disagree. But $57.3 \%$ are in favour of qualifying passed subjects with at least one grade equivalent to the average of the records. That is, the grades made online during confinement do not result in a decrease in the previous average grade that was obtained in the months in which they could be performed face-to-face. However, $42.7 \%$ of students disagree with this proposal, even if this means that the overall weighting decreases the previous cumulative grade.

In contrast to the previous division of opinions, it is observed that in $76.5 \%$ of cases, students prefer the option of repeating exams if they are suspended during confinement and non-face-to-face education by COVID 19 and thus have a better chance of not having to pay a new tuition, for the economic cost that would entail. Also, in $63 \%$ of cases, they are in favour of being able to enrol in the next academic year, even if they have not exceeded the minimum number of credits required for this purpose (63.9\%).
When asked about strategies for fairer online evaluation and grading, participants have shown very diverse positions on proposed alternatives: just over half of students (59.5\%) shared the need to establish peer-to-peer co-assessment or evaluation mechanisms that were complementary to the evaluation and qualification of teachers, but $40.5 \%$ disagreed. The proposal to consider selfevaluation as an instrument of evaluation and complementary qualification to that of teachers (66.7\%) received a higher positive evaluation, but a relevant $33.3 \%$ did not share this position or question it.

However, the idea of introducing rubrics describing in detail the expected result for an assignment, project or test to be carried out had an approval of 97.1\%. At this point, $85 \%$ of young people agree with the justification that the rubrics or scales allow evaluating in a more objective way, since they consider that the criteria are explicit and are known by everyone in advance, in addition to providing clear expectations about which are the specific objectives of the subject and how can they be achieved (85.4\%), make it easier for the student to evaluate and review their own work or production before submitting it $(87 \%)$ and clearly indicate to the student and to the teacher the aspects in which they have difficulties and successes and thus help to plan how to improve (84.4\%).

Like the rubrics, proposals regarding the need for direct feedback when an evaluation test has not been passed are also almost generally supported (99.3\%). As well as offering the possibility of performing assignments or volunteer projects to improve or increase the scores obtained (95.2\%).

What is not unanimous is when specific aspects of self-evaluation, peer-to-peer assessment, and shared and negotiated peer-evaluation with teachers are investigated:

In most cases, it is positively valued to introduce coassessment or peer evaluation into Higher Education, but about $60 \%$ of the sample states that evaluation and qualification is a role of teachers and not of students. The participants see advantages of peer evaluation: $70.3 \%$ say that co-assessment allows people to become more actively involved in their learning processes, $73.3 \%$ stand out that is useful for students to strengthen their metacognition and $82.2 \%$ consider it useful to develop skills such as thoughtful and critical thinking, ability to make judgments, argue, etc. However, it is observed that $45.4 \%$ of respondents maintain a certain distance from co-assessment, critically arguing that "it is an excuse to free teachers from doing their work".

This choice may be due to the vision of themselves that students have, because, in $61.5 \%$ of cases, they con- 


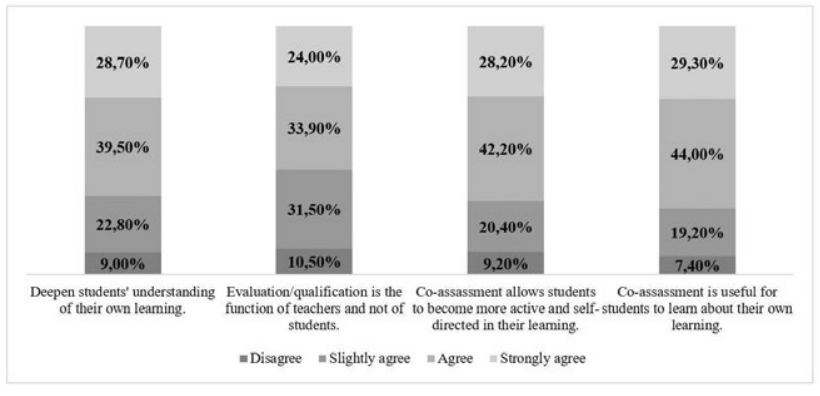

Figure 2. Implications of introducing co-assessment or peer evaluation (\%).

sider that they "lack the knowledge or experience to judge, assess and qualify in a fair and appropriate way the work and the assignment carried out by other classmates". However, the majority (70.5\%) recognize that student involvement increases when teachers share the responsibility to evaluate with them.

Finally, a variety of opinions were noted on the more developed topics in the open questions. In terms of the most developed needs and concerns, 3 categories were identified:

(l) Concerns about online exams: in $30 \%$ of cases, students express their concerns regarding hypothetical situations around online exams (time, pressure, stress, technical difficulties):

One of my biggest concern regarding evaluation is that, in order not to copy, teachers can carry out extreme measures that do not evaluate our actual learning, but how quickly we think (Man, Galicia).

I worry too much about time, I understand that it must be less than one face-to-face, but having exams in which you have 30 seconds to answer each question is both absurd and excessive. Not having enough time to read does not equal not knowing the answer (Woman, Castile and León).

(2) Concerns about the methods used by teachers: in $25 \%$ of cases students express concerns about the inconsistency between the teaching-learning process and applied evaluations (unexplained topics, evaluation criteria, percentages):

There may be teachers who have dedicated themselves to uploading contents without explaining, asking us for much more than what they give us» (Man, Andalucía).

Not all teachers specify what the evaluation of the subject will look like, nor how they will evaluate us or how much the percentages will count (Woman, Castile and León).
(3) Concerns regarding the requirement of evaluations and the number of evaluations that are given during confinement. $20 \%$ of the respondents develop their concerns about the increased demand in the evaluation process (volume of assignments, extension of content, assessment of practices):

What really worries me is not being able to do all the volume of assignment that I have, since I cannot dedicate the hours that require doing so many assignments if I also have online classes (Woman, Andalusia).

I find it absurd that they give the same amount of contents or higher than they would face-to-face (Man, Cantabria).

In terms of personal experiences, various narratives were identified which were grouped into two categories:

(1) Positive evaluation of experiences during confinement:

Some teachers have provided practice test and given us simpler exams so that we do not feel overwhelmed more than we are for the two months of confinement (Woman, Murcia).

We are given facilities when answering our questions or doubts about the agenda (Woman, Valencia).

Positive: In general, I have been working many subjects on my own (Man, Asturias).

(1) Negative evaluation of experiences during confinement:

One teacher disappeared the first 5 weeks of quarantine, another does not tell us what the test is like until the moment of doing it and another one puts us multiplechoice test with half the time we estimate necessary (Man, Castile and León).

I do not understand why in person for an exam there is a set time of about two hours and online is summarized to 30 questions in 30 minutes. In many cases so many of my classmates or even me, have had problems performing the exams and these have been unfinished (Woman, Galicia).

The evaluation of labour practices has been quite poor. Without considering the opinion of the practice centre and only taking as reference a half-memory that I made (Woman, Basque Country). 


\section{DISCUSSION}

The adaptation of face-to-face higher education to a remote and emergency format has led to a drastic and urgent change in the usual forms of evaluation (Blackman et al., 2020) and students have been deeply affected by it.

That is why it is necessary to identify the vision that university students have regarding the online evaluation systems and measures developed and implemented by the universities of the Spanish territory, in order to be able to make informed decisions in order to guide and improve the measures that will continue to be taken and adopted in the face of a hybrid or mixed evaluation as it seems to be to be maintained in a stable way in Higher Education (Pedró, 2020).

As we have seen, most young people consider it necessary to continue evaluating online during a crisis stage. They also consider that a fair online evaluation should be a continuous assessment, using a variety of instruments (Yuste et al., 2012), to evaluate progress and the work developed, which makes it easier to distribute the weight of the final grade for the evaluation to be comprehensive (Villarroel \& Bruna, 2019).

Although exams are not ruled out as a tool, they question them, as do facial recognition or virtual surveillance technologies, although there is majority support for the use of anti-plagiarism programs to control written work, projects and portfolios, despite that there are no significant investigations that confirm the increase of "dishonest behaviours" in the online evaluation compared to the face-to-face (Chirumamilla et al., 2020).

Students demand face-to-face alternatives for those who justifiably have not been able to access the evaluation and that tests that need to be attended are postponed. They do not support the overall promotion in these circumstances, but more than half are in favour of the fact that online evaluation does not involve a negative penalty.

There is a unanimous practice in which they can enrol in the next academic year, even if the minimum number of credits required have not been exceeded. In this respect we must not forget that Spanish universities have exponentially increased the cost of their tuition (Langa-Rosado, 2020) and that not passing a subject is a strong economic outlay.

Regarding the introduction of an online evaluation model oriented to learning (Ibarra-Saiz \& RodríguezGómez, 2020), the opinions have been more diverse. Only a part supports online co-assessment mechanisms that are complementary to the evaluation and qualifica- tion of teachers, while there is more consensus on selfevaluation or feedback and e-rubrics (Ferreiro \& Fernández, 2020) as a source of feedback and also in prior agreement with teachers of the evaluation criteria. The rejection of the peer-peer evaluation is argued by stating that the evaluation is a work of the teachers or that the students are not prepared to evaluate their own classmates.

In conclusion, we must highlight the importance of ensuring the right to higher education for all people within a framework of equal opportunities and nondiscrimination (UNESCO, 2020b), which involves implementing pedagogical measures and strategies to move from a culture of examination to a culture of formative evaluation for learning.

\section{REFERENCES}

Abela, J.A. (2002). Las técnicas de análisis de contenido: Una revisión actualizada. Universidad de Granada.

Abella García, V., Grande de Prado, M., García-Peñalvo, F. J. \& Corell, A. (2020) Guía de recomendaciones para la evaluación online en las Universidades Públicas de Castilla y León. Versión 1.1. Universidad de Burgos. http://doi.org/dzp9

ANECA (2020). Estrategia de la ANECA para el aseguramiento de la calidad en la enseñanza virtual. ANECA. https://bit.ly/2Nan1iO

Azambuya Bouzón, M. E. (2020). La Evaluación Educativa: aproximación a un caso de $1^{\circ}$ de la ESO. Márgenes, Revista de Educación de la Universidad de Málaga, 1, 240-262. http://doi.org/dzqb

Barrientos H. E. J. \& López-Pastor, V. (2017). Evaluación orientada al aprendizaje en educación superior: últimas tendencias. Revista Infancia, Educación y Aprendizaje, 3(2), 582-587. http://doi.org/dzqc

Blackman, A., Ibáñez, A. M., Izquierdo, A., Keefer, P., Moreira, M. M., Schady, N. \& Serebrisky, T. (2020). La política pública frente al COVID-19: Recomendaciones para América Latina y el Caribe. BID. https:// bit.ly/3dEw0DP

Bloxham, S., den-Outer, B., Hudson, J. \& Price, M. (2016). Let's stop the pretence of consistent marking: Exploring the multiple limitations of assessment criteria. Assessment \& Evaluation in Higher Education, 41(3), 466-481. http://doi.org/gcphqx

Chirumamilla, A., Sindre, G. \& Nguyen-Duc, A. (2020). Cheating in e-exams and paper exams: the perceptions of engineering students and teachers in Norway. Assessment \& Evaluation in Higher Education, 1, 1-18. http://doi.org/dzqg 
Díez-Gutiérrez, E. \& Gajardo Espinoza, K. (2020). Educar y evaluar en tiempos de Coronavirus: la situación en España. Multidisciplinary Journal of Educational Research, 10(2), 102-134. http://dx.doi.org/10.17583/ remie.2020.5604

EDUCAbase (2020). Estadísticas Educación 2020. EDUCAbase. https://bit.ly/2ZZYJz3

Ferreiro Concepción, J. F. \& Fernández Medina, C. R. (2020). Una mirada a la evaluación por rúbricas a través de las TIC. Mendive, Revista de Educación, 18(1), 92-104.

García-Peñalvo, F. J., Corell, A., Abella García, V. \& Grande de Prado, M. (2020). La evaluación online en la educación superior en tiempos de la COVID-19. Education in the Knowledge Society, 21(12), 1-26. http://doi.org/dzqm

George, D. \& Mallery, M. (2003) Using SPSS for Windows step by step: a simple guide and reference. Allyn \& Bacon.

Government of Spain (2020). Real Decreto 463/2020, de 14 de marzo, por el que se declara el estado de alarma para la gestión de la situación de crisis sanitaria ocasionada por el COVID-19. Boletín Oficial del Estado, 67, March 14, 25390- 25400. https://bit.ly/3gjWThI

Habib, H., González, C., Collazos, C. \& Yousef, M. (2020). Estudio exploratorio en Iberoamérica sobre procesos de enseñanza-aprendizaje y propuesta de evaluación en tiempos de pandemia. Education in The Knowledge Society, 21(9), 2-9. http://dx.doi. org/10.14201/eks.23537

Ibarra-Sáiz, M. S. \& Rodríguez-Gómez, G. (2020). Aprendiendo a evaluar para aprender en la educación superior. Revista Iberoamericana de Evaluación Educativa, 13(1), 5-8. https://bit.ly/39rBEZt

Langa-Rosado, D. (2020). Sobre la impertinencia de las políticas austericidas: algunos efectos y reflexiones desde el ámbito de la Universidad. Revista de Sociología de la Educación-RASE, 13(2), 164-173. http:// doi.org/dzqt

Llorens-Largo, F. \& Fernández, A. (2020, June 21). Coronavirus, la prueba del algodón de la universidad digital. Universídad. https://bit.ly/2Rm917X

López Pastor, V. M. \& Palacios Picos, A. (2012). Percepción de los futuros docentes sobre los sistemas de evaluación de sus aprendizajes. TESI, 13(3), 317-341.

Lozano-Díaz, A., Fernández-Prados, J., Figueredo Canosa, V. \& Martínez Martínez, A. (2020). Impactos del confinamiento por el COVID-19 entre universitarios: Satisfacción Vital, Resiliencia y Capital Social Online. International Journal of Sociology of Education, 0, 79-104. http://dx.doi.org/10.17583/ rise. 2020.5925
Luengo Horcajo F. \& Manso Ayuso, J. (2020). Informe de Investigación COVID19. Voces de docentes y familias. Proyecto Atlántida. https://bit.ly/2ClnPPL

Ministry of Universities (Ed.) (2020). Informe de iniciativas y herramientas de evaluación online universitaria en el contexto del Covid-19. Gabinete del ministro. https://bit.ly/3dkDsUw

Muñoz-Moreno, J. L. \& Lluch Molins, L. (2020). Educación y Covid-19: Colaboración de las Familias y Tareas Escolares. Revista Internacional de Educación para la Justicia Social, 9(3), 2-17. https://bit. ly/2WTcldC

Oliveri, M. E. \& Markle, R. (2017). Continuing a culture of evidence: Expanding skills in higher education. ETS Research Report, 1,1-8. http://doi.org/gfgtdh

Ozamiz-Etxebarria, N., Dosil-Santamaria, M., PicazaGorrochategui, M. \& Idoiaga-Mondragon, N. (2020). Stress, anxiety, and depression levels in the initial stage of the COVID-19 outbreak in a population sample in the northern Spain. Cadernos de Saúde Pública, 36(4), 1-9. https://doi.org/10.1590/0102-311X00054020

Pedró, F. (2020). COVID-19 y educación superior en América Latina y el Caribe: efectos, impactos y recomendaciones políticas. Carolina, 36, 1-15. https://bit. ly/2WXnES0

REACU (ed.) (2020). Acuerdo de REACU de 3 de abril de 2020, ante la situación de excepción provocada por el COVID- 19. REACU. https://bit.ly/3deDjld

Rodríguez-Conde, M. J. \& Herrera García, M. E. (2010). El Espacio Europeo de Educación Superior. In S. Nieto Martín \& M. J. Rodríguez-Conde (Eds.), Investigación y evaluación educativa en la sociedad del conocimiento (pp. 213-238). Universidad de Salamanca.

Saye, J. (2013). Authentic pedagogy: Its presence in social studies classrooms and relationship to student performance on state-mandated tests. Theory \& Research in Social Education, 41, 89-132. http://doi.org/dzqz

Silió, E. (2020, April 24). Los rectores estiman que 36.000 universitarios tienen trabas técnicas para seguir las clases o examinarse. El País. https://bit.ly/2WWGUiq

Torrecillas, C. (2020). El reto de la docencia online para las universidades públicas españolas ante la pandemia del Covid-19. Instituto Complutense de Estudios Internacionales, 16, 2-4. https://bit.ly/3034UCO

Trillo, F. (2005). La evaluación de los estudiantes universitarios. El caso de la Universidad de Santiago de Compostela [Doctoral dissertation, Universidad de Santiago de Compostela]. Universidad de Santiago de Compostela. https://bit.ly/3efX7Gn

UNESCO (2020a). COVID-19: 10 Recommendations to plan distance learning solutions, UNESCO. https://bit. ly/2UY3fvd 
UNESCO (2020b). COVID-19 y educación superior: De los efectos inmediatos al día después. Análisis de impactos, respuestas políticas y recomendaciones. UNESCO. https://bit.ly/3ehquYL

Villarroel, V. \& Bruna, D. (2019). ¿Evaluamos lo que realmente importa? El desafío de la evaluación auténtica en educación superior. Calidad en la educación, 50, 492-509. http://dx.doi.org/10.31619/caledu.n50.729

Villén Sánchez, C. (2020). El profesorado y las tecnologías en tiempos de confinamiento por la pandemia Covid-19. Creencias sobre actitudes, formación, competencia digital e importancia de las TIC en educación [Master dissertation, Universidad de Salamanca]. Universidad de Salamanca. http://hdl.handle. net $/ 10366 / 143691$

Yuste, R., Alonso, L. \& Blázquez, F. (2012). La e-evaluación de aprendizajes en educación superior a través de aulas virtuales síncronas. Comunicar, 20(39), 159-167. https://bit.ly/2YTTlMu

Zimmerman, B.J. (2002). Becoming a Selfregulated Learner: An Overview. Theory into Practice, 41(2), 64-70. http://doi.org/cwgczh

Zubillaga, A. \& Gortazar, L. (Ed.) (2020). COVID-19 y educación: problemas, respuestas y escenarios. Fundación COTEC. https://bit.ly/2N9kV2D 